\section{Vitamin D and Pneumonia in Children: A Case Control Study}

\author{
Kana Ram Jat ${ }^{1,3 *}$, Jasbinder Kaur ${ }^{2}$ and Vishal Guglani ${ }^{3}$ \\ ${ }^{1}$ Department of Pediatrics, All India Institute of Medical Sciences, Delhi, \\ India \\ ${ }^{2}$ Department of Biochemistry, Government Medical College and Hospital, \\ Chandigarh, India
}

${ }^{3}$ Department of Pediatrics, Government Medical College and Hospital, Chandigarh, India

\author{
Abstract \\ Objectives \\ To evaluate Vitamin D levels and its correlation with severity and \\ outcome of pneumonia in children. \\ Design \\ It is a case-control study. \\ Setting \\ The study was conducted at tertiary care centre from Northern \\ India from June 2013 to June 2014. \\ Participants
}

Fifty children of 1 month to 12 years of age admitted with pneumonia were enrolled as cases. Fifty age and sex matched children without pneumonia were taken as controls.

\section{Outcome measures}

Vitamin D levels were compared between the groups and were correlated with severity and outcome of pneumonia.

\section{Results}

The median (IQR) age of cases and controls was $12(5,39)$ months and $12(5,39)$ months respectively. Overall, $76(86.4 \%)$ children were Vitamin $D$ deficient. The median (IQR) Vitamin $D$ levels [cases $6.8(2.0,14.5)$, controls $7.3(4.7,14.6) \mathrm{ng} / \mathrm{ml} ; \mathrm{p}=0.362$ ] and proportions of children having Vitamin $D$ deficiency were similar between the groups. Vitamin $D$ levels were not different among children with pneumonia, severe pneumonia, and very severe pneumonia $(p=0.985)$. Odds ratio of children with pneumonia being Vitamin D deficient was 3.7 (95\% Cl: 0.930, 14.770; p-value 0.066). Vitamin $D$ levels were not correlated with requirement of intensive care management, mechanical ventilation and duration of hospital stay.

*Corresponding author: Kana Ram Jat, Department of Pediatrics, All India Institute of Medical Sciences, Delhi 110029, India, Tel: +91 9868152426; E-mail: drkanaram@gmail.com

Citation: Jat KR, Kaur J, Guglani V (2016) Vitamin D and Pneumonia in Children: A Case Control Study. J Pulm Med Respir Res 2: 004.

Received: March 3, 2016; Accepted: April 16, 2016; Published: May 02, 2016

\section{Conclusion}

Majority (86.4\%) of children were Vitamin D deficient. Vitamin D levels were not different in cases and controls and were not related to severity and outcome of pneumonia.

The study is registered with Clinical Trials Registry of India (Reg. No: CTRI/2013/09/004021).

Keywords: Hospital stay; Pneumonia; Vitamin D

\section{Introduction}

Pneumonia is one of the most common causes of morbidity and mortality in children worldwide. In world, about 150 million children are affected by pneumonia annually [1]. There are about two million deaths annually due to pneumonia in children five years of age [2]. In India, about one-fifth of under-five mortality is attributed to pneumonia [3].

There are numerous risk factors for pneumonia in children e.g., malnutrition, poverty, ethnicity, incomplete vaccination, smoke exposure, and underlying diseases like bronchopulmonary dysplasia and congenital heart diseases $[4,5]$. Despite interventions to control some or more of these factors, pneumonia continues to be a major threat to child health. There is growing interest to identify other risk factors that may contribute to incidence and severity of pneumonia.

Vitamin D had many functions other than bone metabolism. Recently, Vitamin D is found to have anti-infective property through modulation of innate immune system [6,7]. Vitamin D enhances the expression of Vitamin D Receptors (VDR) and increases production of cathelicidin and beta-defensin-2 peptides which acts through toll-like receptors to elicit antimicrobial function against infections [8-13]. Vitamin D also regulates phagocytosis dependent and antibody-dependent macrophages which protect from respiratory infections [14]. In Vitamin D deficiency, there is decreased expression of VDR resulting in impaired clearance of microbes and uncontrolled inflammation that leads to more lung damage with impaired oxygenation. Vitamin D levels are correlated with respiratory infections. Low Vitamin D production during winter season may be one of the reasons for increased respiratory infections during winter $[15,16]$. The hospitalization rate for children with acute respiratory infections was also correlated to skin pigmentation, one of factor determining Vitamin D production in human body [16].

Vitamin D is associated with risk and severity of pneumonia in various studies from world. Higher maternal Vitamin D levels were associated with lower risk of pneumonia in one study [17] but not in other study [18]. In observational studies from Iran [19], Kuwait [20], Egypt [21], Ethiopia [22] and Jordan [23] children with rickets had higher risk of pneumonia compared to children without rickets. In case-control studies, mean Vitamin D levels were significantly lower in children with pneumonia compared to controls [13,24-26]. There are very limited studies from India. We could find only one study from Indapur, India in 2004, where higher Vitamin D levels were associated with lower risk of pneumonia [27]. The study did not assess correlation between Vitamin D levels and outcome of pneumonia [27]. The available studies had mixed results and Vitamin D levels may vary according to regions, therefore, it is worthy to conduct more 
studies on Vitamin D and pneumonia. If Vitamin D is found to have correlated with pneumonia in children, further studies with emphasis on appropriate method for correction of Vitamin D deficiency may be considered. Thus, this study was planned to assess difference in Vitamin D levels in children with pneumonia and without pneumonia and to correlate Vitamin D levels with severity and outcome of pneumonia.

\section{Methods}

This case-control study was conducted at tertiary care centre from Northern India from June 2013 to June 2014. We enrolled 100 children in the study as per feasibility and available funds. We enrolled 50 children with pneumonia as cases and 50 children without pneumonia as controls. Selection of cases: Children of 1 month to 12 years of age admitted with pneumonia were taken as cases. Pneumonia was defined as World Health Organization (WHO) criteria [28] i.e., presence of tachypnea (respiratory rate of more than 60 , more than 50 and more than 40 per minute in children up to two months of age, between 2 month to 12 months and between 1 year to five years of age respectively) with or without chest retractions. In children above 5 years of age, respiratory rate of more than 30 per minute was considered tachypnea. Severity (pneumonia, severe pneumonia and very severe pneumonia) of cases was assessed as per WHO criteria [28]. Children with asthma and tuberculosis were excluded from study. Selection of controls: Children admitted for reasons other than respiratory symptoms and requiring blood sampling were taken as controls. Controls were matched with cases by sex and age ( \pm 2 months one year and \pm 6 months above one year of age). Ethics committee approval was taken before commencing the study. Parent's informed consent was taken before enrolling children into study. Demographic, clinical and laboratory data were collected in predefined data collection performa for each child. Cases were managed as per prevailing protocols of hospital by attending physician. Outcome of cases was recorded as: time to resolution of pneumonia (normal respiratory rate for age, no retractions, no oxygen requirement, and feeding well), duration of hospital stay and final outcome (discharge or mortality). Primary outcome was difference in mean Vitamin D levels between cases and controls. Secondary outcome included: proportion of children with Vitamin D deficiency, insufficiency and sufficiency between cases and controls, and relation of severity and outcome of cases with Vitamin D levels.

Venous blood samples were collected from both cases and controls and were used to measure serum $25[\mathrm{OH}] \mathrm{D}$ levels by Chemiluminiscence assay. Serum 25[OH]D levels of less than $20 \mathrm{ng} / \mathrm{ml}(50 \mathrm{nmol} / \mathrm{L})$, between $20-30 \mathrm{ng} / \mathrm{ml}(50-75 \mathrm{nmol} / \mathrm{L})$, and levels of $30-80 \mathrm{ng} / \mathrm{ml}$ (75-200 nmol/L) were considered Vitamin D deficiency, insufficiency and sufficiency respectively [29-32].

\section{Statistical methods}

We presented continuous variables as mean \pm SD for normally distributed data and as median (IQR) for skewed data and dichotomous data as percentage. The continuous data were compared between the groups using student's $t$ test for normally distributed data and Mann-Whitney test for data with skewed deviation. The dichotomous data were compared using chi-square test. Correlation between duration of hospital stay and Vitamin D levels was calculated using Pearson's coefficient correlation. Finally, odds ratio was calculated for children with pneumonia being Vitamin D deficient. Statistical analysis was done using SPSS Windows software, version 16. P value of less than 0.05 was considered as statistically significant.

\section{Results}

We enrolled a total of 100 subjects: 50 cases and 50 controls. Demographic profile of cases and controls is shown in (Table 1). Age, male/female ratio, month of enrolment, residence, and other demographic parameters were similar among the groups (Table 1). The majority of control subjects had central nervous system problem (seizure, meningitis) or gastrointestinal problems (diarrhea, vomiting).

\begin{tabular}{|c|c|c|c|c|}
\hline \multicolumn{2}{|c|}{ Parameters } & Cases $(n=50)$ & Controls $(n=50)$ & $P$ value \\
\hline \multicolumn{2}{|c|}{ Age (months) median (IQR) } & $12(5,39)$ & $12(8,48)$ & 0.537 \\
\hline \multicolumn{2}{|c|}{ Male: Female } & $31: 19$ & $31: 19$ & 1.000 \\
\hline \multirow{5}{*}{$\begin{array}{l}\text { Month of } \\
\text { enrolment }\end{array}$} & February & 13 & 3 & \multirow{5}{*}{0.070} \\
\hline & March & 7 & 8 & \\
\hline & April & 7 & 11 & \\
\hline & May & 17 & 17 & \\
\hline & June & 6 & 11 & \\
\hline \multirow{6}{*}{$\begin{array}{l}\text { State of } \\
\text { residence }\end{array}$} & Haryana & 13 & 24 & \multirow{6}{*}{0.133} \\
\hline & Chandigarh & 19 & 10 & \\
\hline & Punjab & 11 & 11 & \\
\hline & Uttar Pradesh & 2 & 2 & \\
\hline & $\begin{array}{l}\text { Himachal } \\
\text { Pradesh }\end{array}$ & 3 & 1 & \\
\hline & Other & 2 & 2 & \\
\hline \multicolumn{2}{|c|}{ Number of siblings (median, IQR) } & $1(1,2)$ & $2(1,3)$ & 0.089 \\
\hline \multicolumn{2}{|c|}{$\begin{array}{l}\text { Duration of exclusive breast feed- } \\
\text { ing (months); median, IQR }\end{array}$} & $6(4,6)$ & $6(6,8)$ & 0.143 \\
\hline \multicolumn{2}{|c|}{$\begin{array}{l}\text { Number of children with clinical } \\
\text { rickets }\end{array}$} & 07 & 10 & 0.266 \\
\hline \multicolumn{2}{|c|}{$\begin{array}{l}\text { Number of children having com- } \\
\text { plete immunization }\end{array}$} & 46 & 42 & 0.525 \\
\hline
\end{tabular}

Table 1: Demographic parameters between cases and controls.

Vitamin D levels were not available for 12 patients (5 cases and 7 controls) due to inadequate sample or spilling during processing. Median (IQR) Vitamin D levels for all participants were $6.9(2,14.5)$ $\mathrm{ng} / \mathrm{ml}$ with a minimum of $2.0 \mathrm{ng} / \mathrm{ml}$ to maximum of $40.9 \mathrm{ng} / \mathrm{ml}$ levels. Overall, 76 (86.4\%), 8 (9.1\%), and 4 (4.5\%) children were Vitamin D deficient, insufficient and sufficient respectively. A total of 17 (7 cases, 10 controls) children had clinical rickets and difference between cases and controls was not statistically different (Table 1). The Vitamin D levels were not different between cases and controls (Table 2). Similarly, proportions of children having Vitamin D deficiency were similar among the groups (Table 2). Odds ratio of children with pneumonia being Vitamin D deficient and Vitamin D deficient or insufficient was 3.7 (95\% confidence interval: 0.930, 14.770; p-value 0.066 ) and 3.3 (95\% confidence interval: $0.330,33.024$; p-value 0.355 ) respectively. Hemoglobin levels were also similar between the groups (Table 2).

Calcium, phosphate and alkaline phosphatase levels were similar between cases and controls (Table 2). The levels were categorized as normal, increased or decreased based on laboratory values provided by Nelson textbook of Pediatrics (19 $19^{\text {th }}$ Edition) and again there was no difference among groups (Table 2).

Among cases; 24 (48.0\%), 16 (32\%), and 10 (20\%) children had pneumonia, severe pneumonia, and very severe pneumonia respectively. The median (IQR) Vitamin D levels in three category of pneumonia severity were $6.7(2.0,14.6), 8.6(2.0,11.8), 6.3$ 


\begin{tabular}{|c|c|c|c|c|}
\hline \multicolumn{2}{|c|}{ Parameters } & $\begin{array}{l}\text { Cases } \\
(n=50)\end{array}$ & $\begin{array}{l}\text { Controls } \\
(n=50)\end{array}$ & $P$ value \\
\hline \multicolumn{2}{|c|}{$\begin{array}{l}\text { Vitamin D levels }(\mathrm{ng} / \mathrm{ml}) ; \\
\text { median, IQR }\end{array}$} & $\begin{array}{c}6.8(2.0 \\
14.5)\end{array}$ & $7.3(4.7,14.6)$ & 0.362 \\
\hline \multicolumn{2}{|c|}{ Hemoglobin (gm\%); mean \pm SD } & $9.6 \pm 2.3$ & $9.5 \pm 2.9$ & $\begin{array}{l}0.827(95 \% \mathrm{Cl}: \\
-1.174,1.463)\end{array}$ \\
\hline \multicolumn{2}{|c|}{ Calcium (mg/dl); mean $\pm S D$} & $9.4 \pm 1.7$ & $8.8 \pm 1.8$ & $\begin{array}{l}0.106(95 \% \mathrm{Cl}: \\
-0.125,1.295)\end{array}$ \\
\hline \multicolumn{2}{|c|}{ Phosphate $(\mathrm{mg} / \mathrm{dl})$; mean $\pm \mathrm{SD}$} & $4.7 \pm 1.1$ & $4.6 \pm 1.1$ & $\begin{array}{l}0.679(95 \% \mathrm{Cl}: \\
-0.349,0.534)\end{array}$ \\
\hline \multicolumn{2}{|c|}{$\begin{array}{l}\text { Alkaline phosphatase (IU/L); } \\
\text { median, IQR }\end{array}$} & $\begin{array}{c}162(127 \\
238)\end{array}$ & $204(137,274)$ & 0.302 \\
\hline \multirow{3}{*}{$\begin{array}{c}\text { Vitamin D } \\
\text { status*; }^{*} \text { (\%) }\end{array}$} & $\begin{array}{l}\text { Deficient } \\
(<20 \mathrm{ng} / \mathrm{ml})\end{array}$ & $42(93.3 \%)$ & $34(79.1 \%)$ & \multirow{3}{*}{0.150} \\
\hline & $\begin{array}{l}\text { Insufficient } \\
(20-30 \mathrm{ng} / \mathrm{ml})\end{array}$ & $2(4.4 \%)$ & $6(14.0 \%)$ & \\
\hline & $\begin{array}{l}\text { Sufficient } \\
(>30 \mathrm{ng} / \mathrm{ml})\end{array}$ & $1(2.2 \%)$ & $3(6.9 \%)$ & \\
\hline \multirow{3}{*}{$\begin{array}{c}\text { Calcium levels } \\
\text { (n=cases } 49, \\
\text { control } 47 \text { ) }\end{array}$} & Normal & $25(51.0 \%)$ & $32(68.1 \%)$ & \multirow{3}{*}{0.087} \\
\hline & Нypo & $18(36.8 \%)$ & $14(29.8 \%)$ & \\
\hline & Hyper & $06(12.2 \%)$ & $1(2.1 \%)$ & \\
\hline \multirow{3}{*}{$\begin{array}{c}\text { Phosphate } \\
\text { levels ( } n=\text { cas- } \\
\text { es } 49 \text {, control } \\
47 \text { ) }\end{array}$} & Normal & $38(77.6 \%)$ & $40(85.1 \%)$ & \multirow{3}{*}{0.523} \\
\hline & Нypo & $8(16.3 \%)$ & $6(12.8 \%)$ & \\
\hline & Hyper & $3(6.1 \%)$ & $1(2.1 \%)$ & \\
\hline \multirow{3}{*}{$\begin{array}{c}\text { Alkaline phos- } \\
\text { phatase levels } \\
\text { (n=cases } 49, \\
\text { control } 45)\end{array}$} & Normal & $28(57.1 \%)$ & $30(66.7 \%)$ & \multirow{3}{*}{0.615} \\
\hline & normal range & $16(32.7 \%)$ & $12(26.7 \%)$ & \\
\hline & $\begin{array}{c}\text { Above normal } \\
\text { range }\end{array}$ & $5(10.2 \%)$ & $3(6.7 \%)$ & \\
\hline
\end{tabular}

*Vitamin $\mathrm{D}$ levels could not be assessed in 5 cases and 7 controls.

Table 2: Laboratory parameters between cases and controls.

$(2.0,13.7) \mathrm{ng} / \mathrm{ml}$ respectively ( $\mathrm{p}=0.985$, Kruskal Wallis Test). Thus, Vitamin D levels were not different in children with increasing severity of pneumonia (Figure 1). Thirteen (26\%) children among cases required intensive care management and four (8\%) children required mechanical ventilation. Again, Vitamin D levels were not different in children who required intensive care management and/or mechanical ventilation compared those who did not require it. There was no mortality among enrolled participants. Finally, duration of hospital stay among cases had no relation with Vitamin D levels (Pearson Correlation -.082, p-value 0.739).

\section{Discussion}

The study revealed that majority of children admitted to a tertiary care center were Vitamin D deficient. In this study only $4.5 \%$ children were Vitamin D sufficient. Children admitted with pneumonia and admitted with diseases other than pneumonia had similar Vitamin D levels. Among cases, Vitamin D levels were not associated with severity of pneumonia, requirement of intensive care management/ mechanical ventilation and duration of hospital study.

The previously reported case-control studies on Vitamin D and Lower Respiratory Tract Infection (LRTI) in children are shown in (Table 3). Karatekin et al., [13] compared neonates admitted with ALRI in NICU to healthy neonates and found that Vitamin D levels were significantly lower in neonates with ALRI $(9.12 \pm 8.88 \mathrm{v} / \mathrm{s} 16.33 \pm 13.42$ $\mathrm{ng} / \mathrm{ml} ; \mathrm{p}=0.011$ ) and Vitamin D levels $<10 \mathrm{ng} / \mathrm{ml}$ were more likely to develop ALRI (OR: 4.25; 95\% CI 1.058-17.070; $\mathrm{P}=0.041$ ). MacNally et al., [24] compared children of less than 5 years of age admitted with pneumonia/bronchiolitis to patients without respiratory

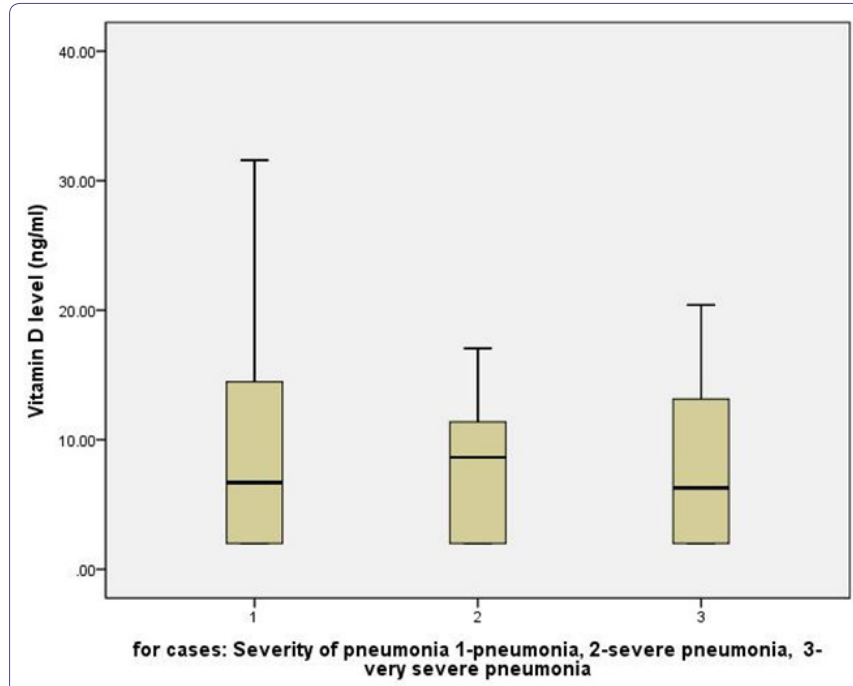

Figure 1: Vitamin D levels as per severity of pneumonia.

symptoms and found no difference in mean Vitamin $\mathrm{D}$ levels between two groups $(81 \pm 40 \mathrm{v} / \mathrm{s} 83 \pm 30 \mathrm{nmol} / \mathrm{L} ; \mathrm{p}=0.71)$ but the cases requiring PICU admission had significantly lower Vitamin D levels compared to both controls and those admitted to ward. Muhe et al., [25] compared children of less than 5 years of age admitted with pneumonia to those admitted without pneumonia and there was 13-fold higher incidence of rickets among children with pneumonia than controls ( 13.37 [95\% CI 8.08-24.22], $\mathrm{p}<0 \cdot 001)$. Oduwole et al., [33] did not observe difference in Vitamin D levels in children of 2 months to 5 years of age admitted with pneumonia compared to those without pneumonia $(104 \pm 59 \mathrm{v} / \mathrm{s} 130 \pm 107 \mathrm{nmol} / \mathrm{L} ; \mathrm{p}>0.05)$. Roth et al., [26,34] reported no difference in Vitamin D levels in children of 1 month to 2 years of age admitted for pneumonia compared to controls in the study conducted at Canada [34] but Vitamin D levels were significantly lower in children with pneumonia in the study conducted at Bangladesh [26]. Wayse et al., [27] from India observed significantly lower Vitamin D levels in children of 2 months to 5 years of age with severe pneumonia compared to healthy controls $(22.8,95 \%$ CI $21.0-24.7 \mathrm{v} / \mathrm{s} 38.4$, 95\% CI 34.2-43.1 $\mathrm{nmol} / \mathrm{l} ; \mathrm{p}<0.001)$. There are few Randomized Controlled Trials (RCTs) evaluating the effect of Vitamin D supplementation in Lower Respiratory Tract Infection (LRTI) in children [35-38]. All except one [38] RCT concluded that Vitamin D supplementation was not beneficial in preventing or treating LRTI in children.

There may be several reasons for Vitamin D being similar among cases and controls in present study. First is overall high prevalence of Vitamin D deficiency among studied children; a large proportion of both case and controls were Vitamin deficient. Secondly we took admitted children without pneumonia as controls instead of healthy controls. As Vitamin D had anti-inflammatory and anti-infective properties and children with other diseases may have Vitamin D deficiency also. We did this intentionally to evaluate the role of Vitamin D in pneumonia specifically; therefore, we wanted cases and controls to be similar in almost all aspects except pneumonia. The ideal study to see association between Vitamin D and pneumonia should measure Vitamin D at birth and than at regular intervals and to follow children for development of pneumonia; but we could not do this because of lack of funding.

The strength of study is age and sex matched controls and prospective study. One limitation of study is lack of healthy controls. 


\section{Conclusion}

Majority of children admitting to a tertiary care center in north India are Vitamin $\mathrm{D}$ deficient. Vitamin $\mathrm{D}$ levels are not different in children with pneumonia as compared to children without pneumonia. Vitamin D levels were not related to severity and outcome of pneumonia among cases.

The trial is registered at Clinical Trial Registry of India (CTRI) with registration No. CTRI/2013/09/004021.

\section{Conflict of Interest: None.}

\section{Ethics Committee Approval}

The study was approved by Institute's ethics committee.

\section{Acknowledgement}

We acknowledge Dr. SK Kabra and Dr. Rakesh Lodha (both from Department of Pediatrics, All India Institute of Medical Sciences, New Delhi, India) for their intellectual input in final manuscript.

\section{References}

1. Bhutta ZA (2007) Dealing with childhood pneumonia in developing countries: how can we make a difference? Arch Dis Child 92: 286-288.

2. Wardlaw T, Salama P, Johansson EW, Mason E (2006) Pneumonia: the leading killer of children. Lancet 368: 1048-1050.

3. Tessa MW, White JE, Matthew H (2006) Pneumonia: The Forgotten Killer of Children. UNICEF, WHO, Geneva, Switzerland.

4. Welliver RC (2003) Review of epidemiology and clinical risk factors for severe Respiratory Syncytial Virus (RSV) infection. J Pediatr 143: 112-117.

5. Hassan MK, Al-Sadoon I (2001) Risk factors for severe pneumonia in children in Basrah. Trop Doct 31: 139-141.

6. Holick MF (2007) Vitamin D deficiency. N Engl J Med 357: 266-281.

7. Adams JS, Hewison M (2008) Unexpected actions of Vitamin D: new perspectives on the regulation of innate and adaptive immunity. Nat Clin Pract Endocrinol Metab 4: 80-90.

8. Walker VP, Modlin RL (2009) The Vitamin D connection to pediatric infections and immune function. Pediatr Res 65: 106-113.

9. Belderbos ME, Houben ML, Wilbrink B, Lentjes E, Bloemen EM, et al. (2011) Cord blood Vitamin D deficiency is associated with respiratory syncytial virus bronchiolitis. Pediatrics 127: 1513-1520.

10. Mohamed WA, Al-Shehri MA (2013) Cord blood 25-hydroxy Vitamin D levels and the risk of acute lower respiratory tract infection in early childhood. J Trop Pediatr 59: 29-35.

11. Haider N, Nagi AG, Khan KM (2010) Frequency of nutritional rickets in children admitted with severe pneumonia. J Pak Med Assoc 60: 729-732.

12. Inamo $Y$, Hasegawa M, Saito K, Hayashi R, Ishikawa T, et al. (2011) Serum Vitamin $D$ concentrations and associated severity of acute lower respiratory tract infections in Japanese hospitalized children. Pediatr Int 53: 199-201.

13. Karatekin G, Kaya A, Salihoğlu O, Balci H, Nuhoğlu A (2009) Association of subclinical Vitamin $D$ deficiency in newborns with acute lower respiratory infection and their mothers. Eur J Clin Nutr 63: 473-477.

14. Raloff J (2006) The antibiotic Vitamin. Deficiency in Vitamin D may predispose people to infection. Science News 170: 312-317.

15. Yorita KL, Holman RC, Steiner CA, Effler PV, Miyamura J, et al. (2007) Severe bronchiolitis and respiratory syncytial virus among young children in Hawaii. Pediatr Infect Dis J 26:1081-1088.

16. Grant WB (2008) Variations in Vitamin D production could possibly explain the seasonality of childhood respiratory infections in Hawaii. Pediatr Infect Dis J 27: 853 .
17. Morales E, Romieu I, Guerra S, Ballester F, Rebagliato M, et al. (2012) Maternal Vitamin D status in pregnancy and risk of lower respiratory tract infections, wheezing, and asthma in offspring. Epidemiology 23: 64-71.

18. Carroll KN, Gebretsadik T, Larkin EK, Dupont WD, Liu Z, et al. (2011) Relationship of maternal Vitamin $D$ level with maternal and infant respiratory disease. Am J Obstet Gynecol 205: 215.

19. Salimpour R (1975) Rickets in Tehran. Study of 200 cases. Arch Dis Child 50: 63-66.

20. Lubani MM, al-Shab TS, al-Saleh QA, Sharda DC, Quattawi SA, et al. (1989) Vitamin-D-deficiency rickets in Kuwait: the prevalence of a preventable disease. Ann Trop Paediatr 9: 134-139.

21. Lawson DE, Cole TJ, Salem SI, Galal OM, el-Meligy R, et al. (1987) Etiology of rickets in Egyptian children. Hum Nutr Clin Nutr 41: 199-208.

22. Auss-Kettis A, Bjornesjo KB, Manneimer E, Cvibach T, Clark P, et al. (1965) Rickets in Ethiopia. The occurrence and clinical picture of the disease in the experiences of a Pediatric Clinic in Addis Ababa. Ethiopia Med J 3: 109-121.

23. Najada AS, Habashneh MS, Khader M (2004) The frequency of nutritional rickets among hospitalized infants and its relation to respiratory diseases. $J$ Trop Pediatr 50: 364-368.

24. McNally JD, Leis K, Matheson LA, Karuananyake C, Sankaran K, et al. (2009) Vitamin D deficiency in young children with severe acute lower respiratory infection. Pediatr Pulmonol 44: 981-988.

25. Muhe L, Lulseged S, Mason KE, Simoes EA (1997) Case-control study of the role of nutritional rickets in the risk of developing pneumonia in Ethiopian children. Lancet 349: 1801-1804.

26. Roth DE, Shah R, Black RE, Baqui AH (2010) Vitamin D status and acute lower respiratory infection in early childhood in Sylhet, Bangladesh. Acta Paediatr 99: 389-393.

27. Wayse V, Yousafzai A, Mogale K, Filteau S (2004) Association of subclinical Vitamin $D$ deficiency with severe acute lower respiratory infection in Indian children under 5 y. Eur J Clin Nutr 58: 563-567.

28. WHO (1995) The Management of Acute Respiratory Infection in Children: Practical Guidelines for Outpatient Care. WHO, Geneva, Switzerland.

29. Holick MF (2007) Vitamin D deficiency. N Engl J Med 357: 266-281.

30. Thomas MK, Lloyd-Jones DM, Thadhani RI, Shaw AC, Deraska DJ, et al. (1998) HypoVitaminosis D in medical inpatients. N Engl J Med 338: 777-783.

31. Heaney RP, Dowell MS, Hale CA, Bendich A (2003) Calcium absorption varies within the reference range for serum 25-hydroxy Vitamin D. J Am Coll Nutr 22: 142-146.

32. Vieth R, Bischoff-Ferrari H, Boucher BJ, Dawson-Hughes B, Garland CF, et al. (2007) The urgent need to recommend an intake of Vitamin $D$ that is effective. Am J Clin Nutr 85: 649-650.

33. Oduwole AO, Renner JK, Disu E, Ibitoye E, Emokpae E (2010) Relationship between Vitamin $D$ levels and outcome of pneumonia in children. West Afr $J$ Med 29: 373-378.

34. Roth DE, Jones AB, Prosser C, Robinson JL, Vohra S (2009) Vitamin D status is not associated with the risk of hospitalization for acute bronchiolitis in early childhood. Eur J Clin Nutr 63: 297-299.

35. Choudhary N, Gupta P (2012) Vitamin D supplementation for severe pneumonia--a randomized controlled trial. Indian Pediatr 49: 449-454.

36. Manaseki-Holland S, Maroof Z, Bruce J, Mughal MZ, Masher MI, et al. (2012) Effect on the incidence of pneumonia of Vitamin $D$ supplementation by quarterly bolus dose to infants in Kabul: a randomised controlled superiority trial. Lancet 379: 1419-1427.

37. Manaseki-Holland S, Qader G, Isaq Masher M, Bruce J, Zulf Mughal M, et al. (2010) Effects of Vitamin D supplementation to children diagnosed with pneumonia in Kabul: a randomised controlled trial. Trop Med Int Health 15: 1148-1155.

38. Camargo CA Jr, Ganmaa D, Frazier AL, Kirchberg FF, Stuart JJ, et al. (2012) Randomized trial of Vitamin D supplementation and risk of acute respiratory infection in Mongolia. Pediatrics 130: 561-567. 